Supplement 1,

Band 22,

Dezember 2006

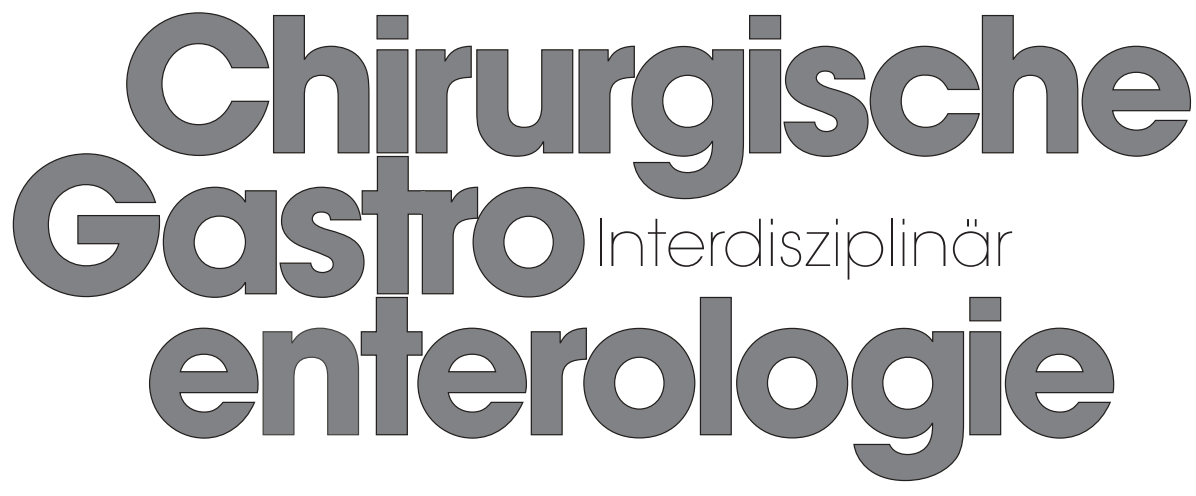

Reinhard Bittner, Stuttgart Wolfgang Kruis, Köln (Hrsg.)

\title{
Viszeralmedizin - State of the Art
}




\section{Band 22, Supplement 1, Dezember 2006}

Editorial

V Auf dem Weg zur Viszeralmedizin Bittner, R. (Stuttgart); Kruis, W. (Köln)

Übersichtsarbeiten

1 Resektionsausmaß und Therapiekonzept bei hereditären nicht Polyposis-assoziiertem kolorektalem Karzinom (HNPCC) - Indexpatient: Chirurgische Strategie Pistorius, S. (Dresden)

6 Interdisziplinäre Sonographie bei akutem Abdomen gastroenterologische Perspektive

Schacherer, D.; Schlottmann, K. (Regensburg)

15 Indikation zur chirurgischen Therapie der Sigmadivertikulitis aus der Sicht des Chirurgen Junghans, T.; Schwenk, W. (Berlin)

21 Chronische Pankreatitis und Schmerz - Chirurgische Sicht Müller, S.A.; Welsch, T.; Kleeff, J.; Schmied, B.M.; Büchler, M.W.; Friess, H.; Schmidt, J. (Heidelberg)

27 Ultraschall bei akutem Abdomen aus der Sicht der Chirurgie Zielke, A. (Offenbach)

33 Indikation zur chirurgischen Therapie der Sigmadivertikulitis aus der Sicht des Gastroenterologen

Damian, U.; Riemann, J.F. (Ludwigshafen)

38 Resektionsausmaß und Therapiekonzept bei Verdacht auf hereditäres, nichtpolypöses kolorektales Karzinom Sicht des Gastroenterologen

Andus, T. (Stuttgart)

43 Gastroösophageale Refluxkrankheit: wirklich ein interdisziplinäres Krankheitsbild in der Viszeralmedizin? Koop, H. (Berlin)

48 Cholezystolithiasis - ein Wandel im interdisziplinären Vorgehen?

Pusl, T.; Hüttl, T.P.; Beuers, U. (München)

53 Interdisziplinäres Vorgehen bei Stenosen und Fisteln bei Morbus Crohn Hoffmann, J.C. (Berlin)

60 Chronische Pankreatitis und Schmerz - eine interdisziplinäre Herausforderung Rünzi, M.; Rehbehn, K.-U. (Essen)

\section{Vol. 22, Supplement 1, December 2006}

Editorial

V On the Way to Visceral Medicine Bittner, R. (Stuttgart); Kruis, W. (Köln)

Review Articles

1 Extent of Resection and Conception of Treatment in Patients with Hereditary Nonpolyposis Colorectal Cancer Index Patient: Surgical Strategy Pistorius, S. (Dresden)

6 Interdisciplinary Sonography in the Acute Abdomen Gastroenterological Perspective Schacherer, D.; Schlottmann, K. (Regensburg)

15 Management of Sigmoid Diverticulitis from a Surgical View Junghans, T.; Schwenk, W. (Berlin)

21 Chronic Pancreatitis and Pain - Surgical View Müller, S.A.; Welsch, T.; Kleeff, J.; Schmied, B.M.; Büchler, M.W.; Friess, H.; Schmidt, J. (Heidelberg)

27 Sonography in Acute Abdomen from the Surgical Point of View Zielke, A. (Offenbach)

33 Indication for Surgical Therapy of Sigmadiverticulitis Seen from the View of the Gastroenterologist Damian, U.; Riemann, J.F. (Ludwigshafen)

38 Type of Resection and Concept of Treatment in Index Patients with Hereditary Non-Polypous Colorectal Carcinoma - Gastroenterologist's View Andus, T. (Stuttgart)

43 Gastro-Oesophageal Reflux Disease Really an Interdisciplinary Disease? Koop, H. (Berlin)

48 Gallbladder Stones - a Change in the Interdisciplinary Approach? Pusl, T.; Hüttl, T.P.; Beuers, U. (München)

53 Interdisciplinary Approach to the Treatment of Stenosis and Fistulae in Crohn's Disease Hoffmann, J.C. (Berlin)

60 Chronic Pancreatitis and Pain - an Interdisciplinary Challenge Rünzi, M.; Rehbehn, K.-U. (Essen) 